\title{
Safety of Anastomoses in Right Hemicolectomy for Colon Cancer
}

\author{
Etele Élthes Előd ${ }^{1}$, Alexandra Cozlea ${ }^{2}$, Radu Mircea Neagoe ${ }^{1,3}$, Daniela Sala ${ }^{1,3}$, Ruxandra Darie', Kálmán Sárdi', \\ Árpád Törö̈k,
}

${ }^{1} 2^{\text {nd }}$ Surgery Department, Mureș County University Hospital, Târgu Mureș, Romania ${ }^{2}$ Gynaecology Department, Mureș County University Hospital, Târgu Mureș, Romania ${ }^{3}$ University of Medicine and Pharmacy Târgu Mureș, Romania

Corresponding author: Alexandra Cozlea, MD Gynaecology Department Mures County University Hospital 1, Alea Zenitului, Livezeni Mureș County, Romania E-mail: alexandra.cozlea@gmail.com

$$
\begin{aligned}
& \text { Abbreviations: } \\
& \text { AL - Anastomotic leakage; } \\
& \text { SG - Study Goup; } \\
& \text { CG - Control Goup; } \\
& \text { OR - Odds Ratio; } \\
& \text { DP - Deceased Patients; } \\
& \text { SP - Survived Patients. }
\end{aligned}
$$

\section{Rezumat}

Siguranta anastomozelor în hemicolectomiile drepte, efectuate în tratamentul cancerului colorectal

Introducere: Cancerul colorectal este unul dintre cele mai frecvent întâlnite tumori maligne ale sistemului digestiv, incidența acestei boli crude crescând constant.

Materiale şi Metode: 236 de pacienți diagnosticați cu cancer de colon drept au fost revizuiți retrospectiv. Pentru toți pacienții incluşi în acest studiu, hemicolectomie dreaptă sau hemicolectomie dreaptă extinsă cu anastomoză ileo-colonică a fost efectuată. Pacienții au fost împărțiți în două grupuri: grupul de studiu incluzând pacienți care au dezvoltat fistulă de anastomoză şi grupul de control, incluzând pacienți fără fistulă. Date clinice, chirurgicale, postoperatorii şi împrejurările apariției fistulelor anastomotice (AL) au fost evaluate. Studiul investighează posibilii factori de risc şi de protecție pentru dezvoltarea fistulelor anastomotice şi nu în ultimul rând studiează relația dintre fistulă de anastomoză şi mortalitatea.

Rezultate: factori de risc cum ar fi vârstă înaintată, tumorile 1/3 drepte ale colonului transvers, interventiile chirurgicale de urgență, sutură mecanică, anastomoza L-T, reluarea tardivă a motilității intestinale au fost identificate în timpul cercetării. Anastomoza L-L a fost identificată ca factor protector în dezvoltarea fistulei de anastomoză.

Concluzii: Conform rezultatelor cercetării, în cazul tumorilor colonului drept, anastomoza ileo-transversă L-L ar trebui adaptată, având ceea mai scăzută rată în ceea ce priveşte dezvoltarea fistulei de anastomoză. 
Cuvinte cheie: cancer de colon, hemicolectomie dreapta, siguranță, fistulă de anastomoză, mortalitate

\begin{abstract}
Introduction: Colorectal cancer is one of the most common malignant tumor of the digestive system, the incidence of this cruel disease has been increasing at a constant rate.

Materials and methods: 236 patients diagnosed with right colon cancer were retrospectively reviewed. For all patients included in this study, right hemicolectomy or extended right hemicolectomy with ileo-colonic anastomosis was performed. Patients were divided in two groups, as follows: study group including patients which developed anastomotic leakage, and control group including patients without anastomotic leak. There were compared clinical, surgical, postoperative and anastomotic leakage (AL) related data within the two groups. The study investigates possible risk and protective factors for developing anastomotic leakage, furthermore the relationship between anastomotic leakage and mortality was analyzed.

Results: risk factors for AL as advanced age, tumors of the right 1/3 of transvers colon, emergencysurgery, mechanical suture, S-E anastomosis, late start of bowel motility were identified during the current research. S-S anastomotic technique were identified as protective factor in the development of fistula.

Conclusion: According to the results of the present research, in right colon tumors S-S anastomotic technique should be used, being linked with the lowest chances of anastomotic leakage.
\end{abstract}

Key words: colon cancer, right hemicolectomy, safeness, anastomotic leakage, mortality

\section{Introduction}

Colorectal cancer is one of the most common malignant tumor of the digestive system, representing approximately $8-10 \%$ of all patients suffering from any type of tumor. The incidence of this cruel disease has been increasing at a constant rate, right sided malignant tumors presenting an occurrence of nearly $35 \%$, which makes right hemicolectomy a common surgical intervention for colorectal surgeons (1).

Anastomotic leakage (AL) represents a feared complication of gastrointestinal surgery, which is responsible for higher postoperative morbidity and mortality, also with possible poor oncological outcomes (2). Anastomotic leakage in colorectal surgery rates second (5.1\%), after esophageal fistula (9.7\%) subsequently surgery for esophageal cancer (3). The incidence of colorectal anastomotic leak varies depending on the localization of anastomosis, more often higher (1-20\%) in low rectal anastomoses (colorectal/ coloanal/ ileoanal), reduced in colocolonic anastomoses (0-2\%) and from 0.02 to 4 $\%$ in ileo-colonic anastomoses (4-5).

Despite advanced surgical tehniques, new surgical instruments and improved medical technology, anastomotic leakage remains a serious complication in colorectal surgery, with life threatening complications and possible catastrophic outcomes.

\section{Materials and Methods}

A total of 236 patients diagnosed with right colon cancer between January 2017 and December 2018 who were admitted and followed the surgical treatment at the $2^{\text {nd }}$ Department of General Surgery of Mures County Emergency Clinical Hospital, Targu Mures, were included in a retrospective casecontrol study. For all patients included in the 
present research, right hemicolectomy or extended right hemicolectomy with ileo-colic anastomosis was performed.

In the first part of the study, patients were selected and divided in two groups, based on the presence or absence of anastomotic leakage (AL), as follows: Study Goup - including 12 patients which developed AL, and Control Goup - including 224 patients without anastomotic leak. In order to deduce safetyness of hand-sewn and stapled anastomosis, for all patients were gathered data regarding clinical, surgical, postoperative and anastomotic leakage aspects. Clinical characteristics included patients' age, gender, admission type, and location of the tumor. The analyzed surgical data comprised the type of performed surgery, ileo-colonic anastomosis, execution of anastomosis, suture layers, type of suture, suture materials, intraoperative blood loss and duration of surgery. Postoperative data compared between the two groups included start of bowel motility and the start of oral feeding.

In the second part of the study, patients were regrouped as follows: Deceased - including 10 patients who suffered death, respectively Survived - including 226 patients presented a favorable evolution. For analyzing the relationship between anastomotic leakage and mortality, there were evaluated the following data: presence of anastomotic fistula and day of appearance of anastomotic leak.

Furthermore, the present study investigates possible risk and protective factors for developing anastomotic leakage and observes the impact of this severe postoperative complication on the prognosis of patients.

Mentioned data was retrospectively gathered from the medical records and collected information was processed using Microsoft Excel. The statistical analysis of the database was performed using GraphPad InStat software (GraphPad Software, Inc., San Diego, United States of America). Quantitative variables were presented by mean and median, while qualitative and categorical variables were expressed both as integer and percentage values. A normality test was applied for all variable groups in order to determine the distribution of values. Furthermore, for the quantitative statistical analysis, Student's t-test was applied for groups with Gaussian distribution of values, while Mann-Whitney nonparametric test was used for groups with non-Gaussian distribution. Inferential statistical analysis involving odds ratios determination for mentioned clinical, surgical and postoperative factors was performed using Fisher's Exact Test. The level of statistical significance for the present research was set at a $p$ value of 0.05 , while the confidence interval was $95 \%$ for all the calculated parameters.

\section{Results}

Table 1 shows the clinical characteristics of patients, age being the first followed character, most of patients being aged over 50 years old. Mean age for SG was 73.5 years old, while in case of CG, mean age was 69.78 years old. There was observed that odds ratios increased with aging, age over 75 years old possibly being a risk factor for developing anastomotic leakage, OR $=2.164$, but without statistical significance. Also, there was remarked a higher percentage of male patients in both groups (SG - 66.7\%, CG - 54\%). In most cases, patients benefited from surgery for colon cancer via chronic hospital admission, emergency surgery being performed in a lower percentage determined as a statistically significant risk factor for developing anastomotic leakage $(\mathrm{OR}=$ 3.610, $\mathrm{P}=0.042$ ). While examining the most frequent locations of right sided colon tumors, was detected a majority of coecum and ascending localization. There was also noticed that tumors of the right $1 / 3$ transvers colon, were a risk factor for anastomotic leakage $(\mathrm{OR}=4.591$, $\mathrm{P}=0.031$ ).

In Table 2 surgical assessment is shown. For all patients included in this study, right colectomy (SG $-100 \%$, CG $-87.1 \%$ ) or extended right hemicolectomy $(\mathrm{CG}-12.9 \%)$ was performed. While performing these surgical interventions, hand-sewn (SG - 58.33\%, CG $85.7 \%$ ) or stapled ( $\mathrm{SG}-41.67 \%$, CG $-14.3 \%$ ) ileo-transvers anastomosis was achieved, 
Table 1. Clinical characteristics

\begin{tabular}{lcccc}
\hline & $\begin{array}{c}\text { Study Group } \\
\text { (Patients with } \\
\text { anastomotic leakage) } \\
\mathbf{n}=\mathbf{1 2}(\%)\end{array}$ & $\begin{array}{c}\text { Control Group } \\
\text { (Patients with } \\
\text { anastomotic integrity) } \\
\mathbf{n}=\mathbf{2 2 4}(\%)\end{array}$ & Odds Ratio & P value \\
\hline Age & $0(0)$ & $20(8.9)$ & 0.399 & 0.6062 (NS) \\
$25-50$ years old & $5(41.7)$ & $116(51.8)$ & 0.665 & 0.5628 (NS) \\
$51-75$ years old & $7(58.3)$ & $88(39.3)$ & 2.164 & 0.2320 (NS) \\
$>75$ years old & 73.5 & 69.78 & - & 0.5083 (NS) \\
$\quad$ Mean age (years) & & & & \\
Gender & $8(66.7)$ & $121(54)$ & 1.702 & 0.5542 (NS) \\
$\quad$ Males & $4(33.3)$ & $103(46)$ & 0.587 & 0.5542 (NS) \\
$\quad$ Females & $7(66.7)$ & $187(80.4)$ & 0.277 & 0.0424 \\
Admission type & $5(33.3)$ & $37(19.6)$ & 3.610 & 0.0424 \\
$\quad$ Chronic & & & & \\
$\quad$ Emergency & $2(16.7)$ & $56(25)$ & 0.600 & 0.7352 (NS) \\
Tumor location & $6(50)$ & $105(46.9)$ & 1.133 & 1.0000 (NS) \\
$\quad$ Ascendent colon & $0(0)$ & $41(18.3)$ & 0.176 & 0.1337 (NS) \\
$\quad$ Coecum & $4(33.3)$ & $22(9.8)$ & 4.591 & 0.0313 \\
$\quad$ Liver flexure & & & &
\end{tabular}

Table 2. Surgical assessment

\begin{tabular}{|c|c|c|c|c|}
\hline & $\begin{array}{c}\text { Study Group } \\
\text { (Patients with } \\
\text { anastomotic leakage) } \\
\mathrm{n}=12(\%)\end{array}$ & $\begin{array}{c}\text { Control Group } \\
\text { (Patients with } \\
\text { anastomotic integrity) } \\
\mathrm{n}=224(\%)\end{array}$ & Odds Ratio & $P$ value \\
\hline \multicolumn{5}{|l|}{ Type of surgery } \\
\hline Right hemicolectomy & $12(100)$ & $195(87.1)$ & 3.772 & 0.3702 (NS) \\
\hline Extended right hemicolectomy & $0(0)$ & $29(12.9)$ & 0.265 & 0.3702 (NS) \\
\hline \multicolumn{5}{|l|}{ Execution of anastomosis } \\
\hline S-E & $7(50)$ & $61(51.8)$ & 3.741 & 0.0427 \\
\hline E-S & $2(16.7)$ & $33(6.3)$ & 1.158 & 0.6938 (NS) \\
\hline S-S & $3(33.3)$ & $130(41.9)$ & 0.241 & 0.0346 \\
\hline \multicolumn{5}{|l|}{ Type of anastomosis } \\
\hline Hand sawn & $7(58.33)$ & $192(85.7)$ & 0.233 & 0.0250 \\
\hline Stapled & $5(41.67)$ & $32(14.3)$ & 4.286 & 0.0250 \\
\hline \multicolumn{5}{|l|}{ Suture layers } \\
\hline Single layers & $6(50)$ & $96(42.9)$ & 1.333 & 0.7669 (NS) \\
\hline Double layer & $6(50)$ & $128(57.2)$ & 0.750 & 0.7669 (NS) \\
\hline \multicolumn{5}{|l|}{ Type of suture } \\
\hline Separated & $3(25)$ & $121(54.02)$ & 0.283 & 0.0730 (NS) \\
\hline Continuous & $4(33.33)$ & $71(31.7)$ & 1.077 & 1.0000 (NS) \\
\hline Mechanical suture & $5(41.67)$ & $32(14.28)$ & 4.286 & 0.0250 \\
\hline \multicolumn{5}{|l|}{ Suture material } \\
\hline Monofilament & $3(25)$ & $73(32.59)$ & 0.689 & 0.7560 (NS) \\
\hline Multifilament & $4(33.33)$ & $119(53.13)$ & 0.441 & 0.2391 (NS) \\
\hline Metal & $5(41.67)$ & $32(14.28)$ & 4.286 & 0.0250 \\
\hline \multicolumn{5}{|l|}{ Duration of surgery } \\
\hline $70-110$ minutes & $1(8.33)$ & $87(38.84)$ & 0.1432 & 0.0347 \\
\hline $110-150$ minutes & $3(25)$ & $52(23.21)$ & 1.103 & 1.0000 (NS) \\
\hline $151-200$ minutes & $8(66.67)$ & $85(37.95)$ & 1.223 & 1.0000 (NS) \\
\hline \multicolumn{5}{|l|}{ Intraoperative blood loss } \\
\hline Mean (ml) & 470 & 460 & - & (NS) \\
\hline
\end{tabular}

NS - statistical not significant $p$ value 
observing that stapled anastomosis increased the risk for anastomotic leak $(\mathrm{OR}=4.286, \mathrm{P}=$ 0.025). The entero-colic anastomoses were performed S-E, E-S, and S-S between the ending intestinal sections. Analyzing the execution modality, there was found that S-S ileo-transvers anastomosis represents a protective factor for anastomotic leakage $(\mathrm{OR}=0.241, \mathrm{P}=0.034)$ and the use of $\mathrm{S}-\mathrm{E}$ anastomosis increases the odds for developing anastomotic leak, with an $\mathrm{OR}=3.741(\mathrm{P}=0.042)$. For suturing the end parts of the bowels, single layer (SG - 50\%, CG - 42.9\%) or double layer (SG - 50\%, CG $57.2 \%)$ sutures were used, without any significant differences. The statistical analysis of the suture procedures (separated/ continuous/ mechanical suture) resulted in significant statistical parameters regarding the risk of anastomotic leak in mechanical sutures $(\mathrm{OR}=$ $4.286, \mathrm{P}=0.025)$. Evaluation of suture material (monofilament/ multifilament/ metal) showed that using metal material for suture, presents and $\mathrm{OR}=4.286(\mathrm{P}=0.025)$ in favor of anastomotic complications. Estimating the duration of surgery, shorter operating time was demonstrated as a protective factor for anastomotic fistula, with an OR produced the identification of shorter surgical intervention as a protective factor in the development of anastomotic fistula, with an $\mathrm{OR}=0.1432, \mathrm{P}=0.034$.

In order to assess start of bowel motility, there were divided two subgroups: average start (1-3 days) and late start ( $>5$ days) of bowel motility. Furthermore, there were distinguished early and late start of oral alimentation. Early start was considered when oral alimentation started at postoperative day 1-2 (6), while in case of late start, the oral alimentation began after return of bowel motility.

Table 3 presents the results observed while analyzing postoperative data. For both groups, average start of bowel motility was noticed in higher percentage ( $\mathrm{SG}-58.34 \%$, CG $-91.52 \%$ ), while late start of bowel motility was identified as a statistically significant risk factor for anastomotic leakage $(\mathrm{OR}=$ 7.707, $\mathrm{P}=0.003$ ).

In order to evaluate the postoperative appearance day of fistulas, there were separated three groups, as follows: early appearance of anastomotic leak (1-4 days), median appearance of fistula (5-10 days) and late appearance of anastomotic leakage (>30 days) (7).

Consequences of anastomotic leakage are presented in Fig. 1. For this section of the study, patients were regrouped depending on mortality, as mentioned before. Were determined high significant odds for decease due to anastomotic fistula $(\mathrm{OR}=18.167, \mathrm{P}=0.0007)$, especially for early appearance of anastomotic complication, with $\mathrm{OR}=71.526$ and $\mathrm{P}=0.042$, presented in Fig. 2.

\section{Discussions}

While evaluating the clinical characteristics of the study groups, age and gender where the first followed aspects. An increased risk for developing anastomotic leakage was observed with aging, patients over 75 years old presenting a possible risk factor, these findings being similar

Table 3. Postoperative data

\begin{tabular}{lcccc}
\hline & $\begin{array}{c}\text { Study Group } \\
\text { (Patients with } \\
\text { anastomotic leakage) } \\
\mathbf{n}=\mathbf{1 2}(\%)\end{array}$ & $\begin{array}{c}\text { Control Group } \\
\text { (Patients with } \\
\text { anastomotic integrity) } \\
\mathbf{n}=\mathbf{2 2 4}(\%)\end{array}$ & Odds Ratio & P value \\
\hline $\begin{array}{l}\text { Start of bowel motility } \\
\text { Average start (1-4 days) } \\
\text { Late start of bowel motility }\end{array}$ & $7(58.34)$ & $205(91.52)$ & 0.1298 & 0.0035 \\
$\quad>5$ days) & $5(41.66)$ & $19(8.48)$ & 7.707 & 0.0035 \\
$\begin{array}{l}\text { Start of oral feeding } \\
\text { Early oral feeding }\end{array}$ & $7(66.7)$ & $130(58.1)$ & 1.012 & 1.0000 (NS) \\
Late oral feeding & $5(33.3)$ & $94(41.9)$ & 0.987 & 1.0000 (NS) \\
\hline
\end{tabular}

NS - statistical not significant $p$ value 
Figure 1. Correlation between mortality and anastomotic leakage

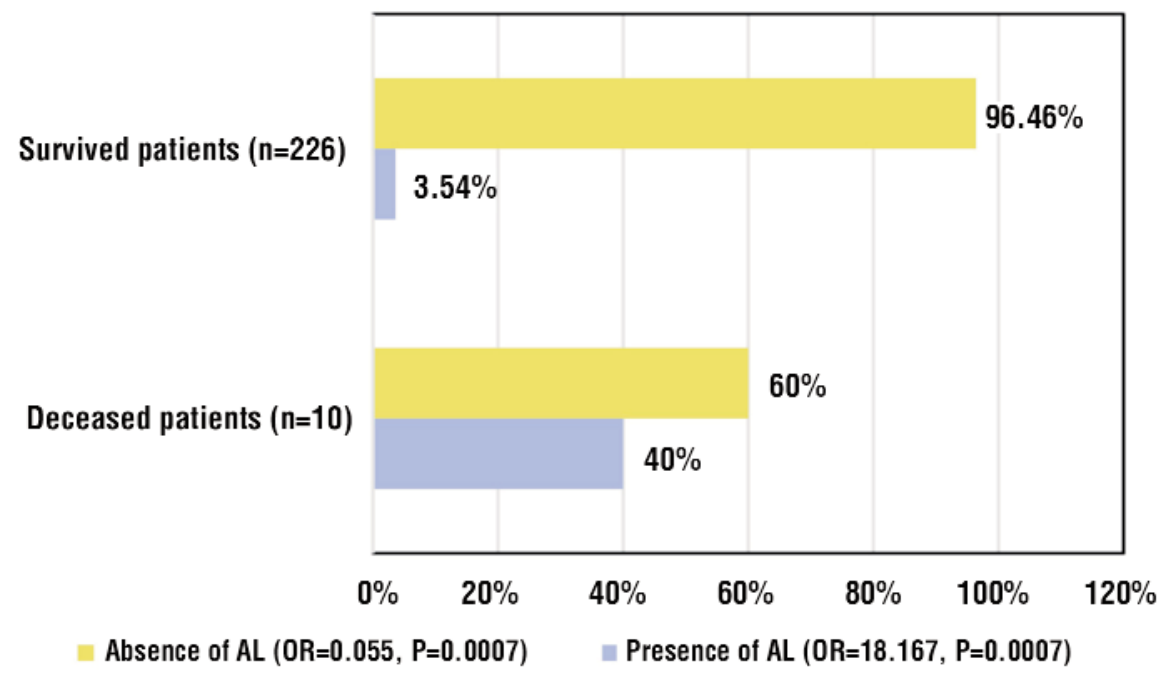

to other authors' reports (8). Analyzing gender, there were identified more male patients in the study group, concluding that male gender is an independent risk factor for anastomotic leak. Other authors reported similar results (9). Furthermore, practicing segmentary resection with anastomosis for colorectal cancer in emergency conditions increased the risk for developing anastomotic fistula, multiple studies reporting close results $(10,11)$. The majority of tumors were localized in the coecum and ascending segments of the large bowel, while presence of a malignant tumor at the right $1 / 3$ of transvers colon was identified as a potentially predisposing factor for anastomotic leakage. Similar results can be found in field literature (12).

Surgical assessment was also performed for the studied patients, focusing on the circumstances and technical aspects of the anastomoses. At the beginning, we analyzed the execution modality, observing that S-E technique is associated with the highest risk of developing anastomotic fistula, being calculated statistically significant odds, while other authors described that E-S variety has the
Figure 2. Early appearance of anastomotic leakage affecting survival

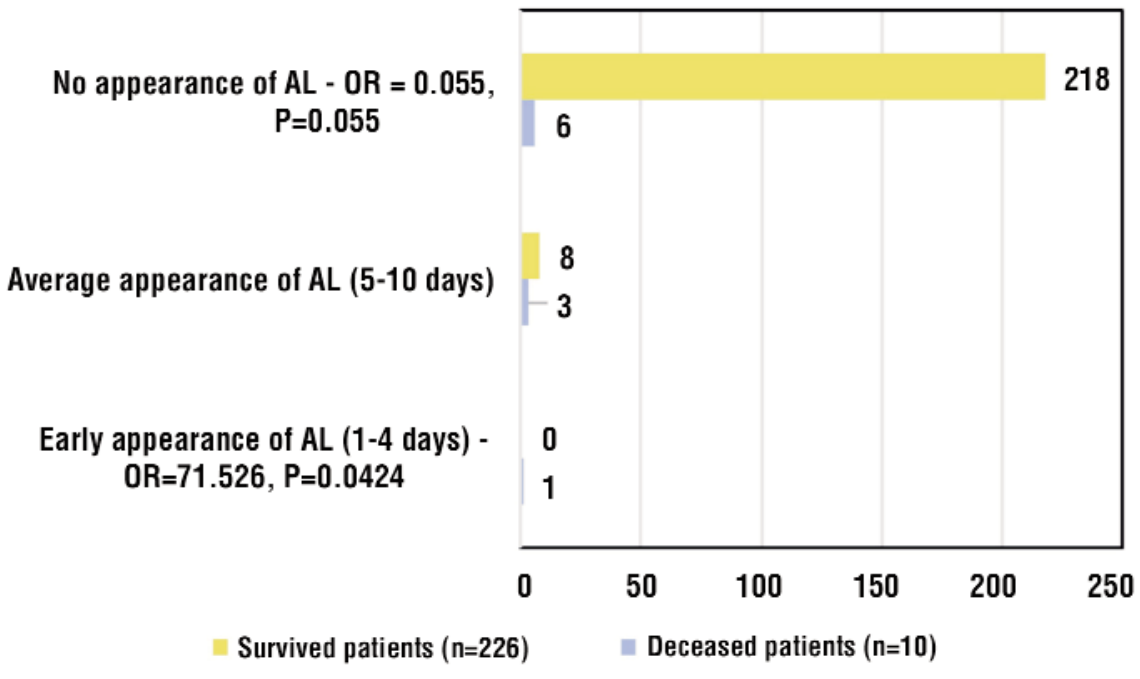


highest risk of association with an anastomotic leakage (13); also, we observed that S-S technique presents the lowest chances of anastomotic leakage and could be considered a protective factor in the development of the fistula (14). Regarding the anastomotic suture layers, we observed similar results concerning single layer and double layer anastomoses, the number of layers showing no influence in the progression through leakage, our results being in accordance to other field researches, which also affirmed no significant differences between suturing in single or double layer (15).

Another aspect regarding the surgical technique was the type of suture, observing that separated and continuous hand sutures were not associated with any influence on the development of anastomotic fistula, while mechanical suture using staplers represented an important risk factor for leakage occurrence; other authors described in a recent report that continuous sutures are associated with a reduction of the anastomotic leakage rate (16). Related to mechanical suture, previous field research affirmed that mechanical stapling in right hemicolectomy is associated with higher anastomotic fistulas when compared to handsewn sutures (17). Last but not least, suture material was evaluated in order to establish its potential involvement in the development of anastomotic leakage, observing that monofilament and multifilament materials had no influence on the progression of the fistula, while metal stitches used during mechanical suturing was an important pawn in developing anastomotic leakage in the studied subjects; other authors reported similar results to ours $(18,19)$.

Choosing the suitable suture technique for ileo-colonic anastomosis while performing right hemicolectomy for colon cancer usually depends on the surgeon's choice, local and technical conditions. During the field research of literature for colonic and colorectal anastomotic techniques, were found several articles promoting stapled procedures, sustaining that mechanical suture presents a lower incidence of anastomotic leak (20). Investigating similar scientific articles there can be found opposite perspectives to ours, affirming that stapled procedure should be preferred for anastomosis after ileocolic resection (21).

Operating time is well known in field literature to contribute to patients' evolution and prognosis (22), fact that requested a time analysis among the subjects included in the present study. There was observed that a shorter operating time was identified as a significant protective factor in the development of the anastomotic fistula, other published studies presenting prolonged duration of surgery as an independent risk factor in the occurrence of anastomotic leakage (23). Furthermore, the assessment of intraoperative blood loss showed no statistical differences in patients with anastomotic leakage, compared to those with anastomotic integrity. Other researchers affirm that increased intraoperative blood loss or need of transfusion increase the risk for developing anastomotic leakage (24).

Postoperative assessment investigated the potential involvement of the bowel motility and oral feeding in the occurrence of anastomotic leakage in studied patients. Field literature describes an average start of bowel motility during the first 1-4 postoperative days, this aspect being identified as a statistically significant protective factor for anastomotic leakage, other published reports affirming similar results to ours (25). We also observed that the restart of oral feeding was not significantly involved in the appearance of the anastomotic leak, findings sustained by other authors reporting that the effect of early oral intake on anastomotic fistula is still unclear (26).

For the last section of the study, patients were regrouped in Deceased Patients (DP) and Survived Patients (SP), willing to prove the influence of the anastomotic leakage on the prognosis of studied subjects, this representing a relevant postoperative complication which increases the morbidity and mortality of patients (27). We observed that patients who developed anastomotic leakage were exposed to an extremely high risk for decease in relation to patients with anastomotic integrity, other published reports being in accordance to our findings (28). We also had into view the day of 
anastomotic fistula appearance, observing that an early leakage was a significant risk factor for death in patients with ileo-colic anastomoses, previous studies presenting similar results $(29,30)$.

\section{Conclusion}

Although considerable medical and technical improvements have been made in the past decade regarding several aspects of performing post-resection intestinal anastomoses, anastomotic leakage remains a major issue in colorectal surgery, representing a critical postoperative complication which increases the morbidity and mortality of patients. Despite the benefits of stapling devices described in field literature, mechanical suture in right hemicolectomy is associated with anastomotic fistulas in high ratios. According to the results of the present research, in right colon tumors S-S anastomotic technique should be used, being linked with the lowest chances of anastomotic leakage, also being considered with high probability a protective factor in the development of the fistula. Furthermore, risk factors as advanced age, tumors of the right $1 / 3$ of transvers colon, emergency surgery, $S$ $\mathrm{E}$ anastomosis, late start of bowel motility were identified during the current research, patients included in these risk groups needing special attention and a more careful follow up during the immediate postoperative period, observing in time potential signs and symptoms that could lead to an anastomotic leakage, also applying the appropriate therapeutically measures in order to avoid degradation of the general status of patients.

\section{Ethical Policies}

For performing this study ethical approval was obtained.

\section{Conflict of Interest}

The authors declare no conflicts of interests.

\section{References}

1. Milovanovic Alempijevic T, Nikolic V, Zec S, Veljkovic A, SokicMilutinovic A, Pavlovic-Markovic A, et al. Change in the incidence and anatomic distribution of colorectal adenoma and cancer over a period of 20 years - A single center experience. Vojnosanit Pregl 2018; 75(3): 260-266.

2. Bakker IS, Grossmann I, Henneman D, Havenga K, Wiggers T. Risk factors for anastomotic leakage and leak-related mortality after colonic cancer surgery in a nationwide audit. Br J Surg 2014; 101(4):424-32.

3. Neagoe RM, Sala D, Voidazan S, Bancu S, Kiss L, Suciu H. Transthoracic versus transhiatal esophagectomy: a permanent dilemma. Our 15-year experience.Chirurgia.2013;108(6):780-787

4. Bodil Gessler, Olle Eriksson, Eva Angenete. Diagnosis, treatment and consequences of anastomotic leakage in colorectal surgery. Int J Colorectal Dis 2017;32(4):549-556.

5. Sciuto A, Merola G, De Palma GD, Sodo M, Pirozzi F, Bracale UM et al. Predictive factors for anastomotic leakage after laparoscopic colorectal surgery. World J Gastroenterol 2018;24(21):2247-2260.

6. Forsmo HM, Erichsen C, Rasdal A, Körner H, Pfeffer F. Enhanced recovery after colorectal surgery (ERAS) in elderly patients is feasible and achieves similar results as in younger patients. Gerontol Geriatr Med 2017; 3: 2333721417706299.

7. Li YW, Lian P, Huang B, Zheng HT, Wang MH, Gu WL, et al. Very early colorectal anastomotic leakage within 5 postoperative days: a more severe subtype needs relaparatomy. Sci Rep 2017; 7:39936.

8. Tian Y, Xu B, Yu G, Li Y, Liu H. Comorbidity and the risk of anastomotic leak in Chinese patients with colorectal cancer undergoing colorectal surgery. Int J Colorectal Dis 2017; 32(7): 947-953.

9. Shogan BD, Carlisle EM, Alverdy JC, Umanskiy K. Do we really know why colorectal anastomoses leak? J Gastrointest Surg 2013; 17(9): 1698-707.

10. MD Calin, C Balalau, F Popa, S Voiculescu, RV Scaunasu. Colic anastomotic leakage risk factors. J Med Life 2013; 6(4): 420-423.

11. Bennis $\mathrm{M}$, Parc $\mathrm{Y}$, Lefevre $\mathrm{JH}$, et al. Morbidity risk factors after low anterior resection with total mesorectal excision and coloanal anastomosis: a retrospective series of 483 patients. Ann Surg 2012; 255:504-510.

12. Bakker IS, Grossmann I, Henneman D, Havenga K, Wiggers T. Risk factors for anastomotic leakage and leak-related mortality after colonic cancer surgery in a nationwide audit. BJS 2014; 101(4): 424-432.

13. Liu Z, Wang G, Yang M, Chen Y, Miao D, Muhammad S, et al. Ileocolonic anastomosis after right hemicolectomy for colon cancer: functional end-to-end or end-to-side?. World J Surg Oncol. 2014; $12: 306$.

14. Frances Goulder. Bowel anastomoses: The theory, the practice and the evidence base. World J Gastrointest Surg 2012; 4(9):208-213.

15. Herrle F, Diener MK, Freudenberg S, Willeke F, Kienle P, Boenninghoff $\mathrm{R}$, et al. Single-layer continuous versus double-layer continuous suture in colonic anastomoses - a randomized multicentre trial (ANATECH Trial). J Gastrointest Surg 2016, 20(2):421-30.

16. Eickhoff $R$, Eickhoff $S B$, Katurman $S$, Klink $C D$, Heise D, Kroh A, et al. Influence of suture technique on anastomotic leakage rate - a retrospective analyses comparing interrupted-versus-continuoussutures. Int J Colorectal Dis. 2019;34(1):55-61.

17. Jessen M, Nerstrom M, Wilbek TE, Roepstorff S, Rasmussen MS, Krarup PM. Risk factors for clinical anastomotic leakage after right hemicolectomy. Int J Colorectal Dis 2016;31(9):1619-24.

18. Gustafsson P, Jestin P, Gunnarsson U, Lindforss U. Higher frequency of anastomotic leakage with stapled compared to hand sewn ileocolic anastomosis in a large population-based study. World J Surg 2015; 39(7):1834-9.

19. Slieker JC, Daams F, Mulder IM, Jeekel J, Lange JF. Systematic review 
of the technique of colorectal anastomosis. Jama Sueg 2013;148(2): 180-201.

20. Goulder F, Bowel anastomoses: The theory, the practice and the evidence base. World J Gastrointest Surg 2012;4(9):208-213.

21. Liu BW, Liu Y, Liu JR, Feng ZX. Comparison on hand-sewn and stapled anatomoses in surgeries of gastrointestinal tumors based on clinical practice of China. World J Surg Oncol. 2014;12:292.

22. Vasiliu EC, Zarnescu NO, Costea R, Neagu S. Review of risk factors for anastomotic leakage in colorectal surgery. Chirurgia (Bucur) 2015;110(4):319-326.

23. Nikolian VC, Kamdar NS, Regenbogen SE, Morris AM, Byrn JC, Suwanabol PA, et al. Anastomotic leak after colorectal resections: a population-based study of risk factors and hospital variation. Surgery 2017;161(6):1619-1627.

24. Dana A Telem, Edward H Chin, Scott Q Nguyen, Celia M Divino. Risk factors for anastomotic leak following colorectal surgery. Arch Surg 2010; 145(4): 371-376.

25. Peters EG, Dekkers M, van Leeuwen-Hilbers FW, Daams F, Hulsewé KWE, de Jonge WJ, et al. Relation between postoperative ileus and anastomotic leakage after colorectal resection: a post hocanalysis of a prospective randomized controlled trial. Colorectal Dis. 2017;
19(7):667-674.

26. Smeets BJJ, Peters EG, Horsten ECJ, Weijs TJ, Rutten HJT, Buurman WA, et al. Effect of early vs late start of oral intake on anastomotic leakage following elective lower intestinal surgery: a systematic review. Nutr Clin Pract. 2018;33(6): 803-812.

27. Frasson M, Flor-Lorente B, Rodríguez JL, Granero-Castro P, Hervás D, Alvarez Rico MA, et al. Risk factors for anastomotic leak after colon resection for cancer: multivariate analysis and nomogram from a multicentric, prospective, national study with 3193 patients. Ann Surg. 2015;262(2):321-30.

28. Tevis SE, Carchman EH, Foley EF, Heise CP, Harms BA, Kennedy GD. Does anastomotic leak contribute to high failure-to-rescue rates? Ann Surg 2016;236(6):1148-1151.

29. Floodeen H, Hallböök O, Rutegțrd J, Sjödahl R, Matthiessen P. et al. Early and late symptomatic anastomotic leakage following low anterior resection of the rectum for cancer: are they different entities? Colorectal Dis. 2013;15(3):334-40.

30. Dauser B, Herbst F. Diagnosis, management and outcome of early anastomotic leakage following colorectal anastomosis using a compression device: is it different? Colorectal Dis 2014;16(12): 435-9. 